\title{
Genetic variability in salt tolerance of selected boreal woody seedlings
}

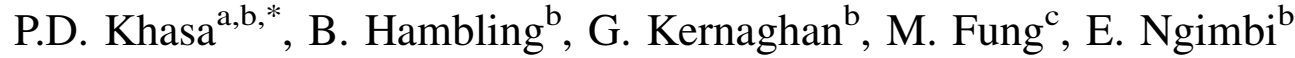 \\ ${ }^{\mathrm{a}}$ Centre de Recherche en Biologie Forestière, Université Laval, Que., Canada G1K 7P4 \\ ${ }^{\mathrm{b}}$ Department of Renewable Resources, University of Alberta, Edmonton, Alta., Canada T6G $2 \mathrm{HI}$ \\ ${ }^{\mathrm{c} S y n c r u d e}$ Canada Ltd., Environmental Affairs Department, P.O. Bag 4009, M.D. 0078, Fort McMurray, Alta., Canada T9H 3 L1
}

Received 4 December 2000; accepted 6 June 2001

\begin{abstract}
In order to select woody plant candidates suitable for revegetation of saline-alkaline soils, we tested selected woody plant species and seed lots: Pinus contorta (lodgepole pine), Pinus banksiana (jack pine), Picea glauca (white spruce), Populus tremuloides (trembling aspen), and Alnus rubra, syn. Alnus oregona (red alder). Pre-germinated seedlings were grown for 4 weeks in a greenhouse in a semi-hydroponic system containing $1 / 2$ strength Hoagland solution with additional sodium concentrations $(0,25,50,75 \mathrm{mM})$ and composite tailings release water. A significant interaction between salt treatments and seed lots within plant species as well as between salt treatments and plant species was observed for weight and necrosis, indicating that the plant genotype responded differently to salt treatments. Of all examined woody plant species, jack pine (Syncrude seed source) exhibited the highest percent survival followed by white spruce (Syncrude seed source), red alder (seed lot No. 40457), and lodgepole pine (seed lot No. 7960007). Proportionately ranked means for dry biomass production showed lodgepole pine (seed lot No. 7960007) with the greatest biomass followed by aspen (seed lot No. Syncrude), red alder (seed lot No. Port Renfrew), jack pine (seed lot No. 8960049) and white spruce (Syncrude seed source). The best performing seed lots based on aggregation index which combines both the percent survival and dry weight averages were: red alder (seed lot Nos. 40457 and 45958), aspen (Syncrude seed source), jack pine (Syncrude seed source), lodgepole pine (seed lot No. 7960007). Based on variance components, most of the variation was explained by the treatment and seed lot effects. This reveals the importance of intra-specific variability and that selection should be based not only on inter-specific variation but also on the intra-specific variation for the development of salt-tolerant lines to be used in reclamation of saline habitats. (C) 2002 Elsevier Science B.V. All rights reserved.
\end{abstract}

Keywords: Inter- and intra-specific variation; $\mathrm{G} \times \mathrm{E}$ interaction; Oil sands; Reclamation; Salt tolerance

\section{Introduction}

Salinity and water logging are a serious threat to food and fiber production worldwide (Khan and

\footnotetext{
* Corresponding author. Present address: Centre de Recherche en Biologie Forestière, Université Laval, Que., Canada G1K 7P4. Tel.: +1-418-656-2131, ext: 12587; fax: +1-418-656-7493. E-mail address: damase.khasa@rsvs.ulaval.ca (P.D. Khasa).
}

Ungar, 1995). The rapidly growing demand for food, fiber, and fuel in the face of rapidly declining productivity of agricultural land due to increased soil salinization makes it imperative that plant production under saline conditions be significantly increased. Salt affected soils make up 954.8 million hectares, or about $10 \%$ of the earth's surface (Szabolics, 1994). In the Canadian prairie, soils contain predominantly sulfate salts as well as some chloride salts (Curtin et al., 
1993). The primary problems associated with salinity and sodicity are reductions in plant productivity due to water stress caused by the increased osmotic potential and changes in soil physical properties (dispersion with a resultant reduction in permeability) when salt or sodium concentrations in soils become too high. It is believed that salt tolerant plants may be of potential use in these degraded agricultural and forest areas to produce food, fiber and other commodities. The influence of physicochemical and biotic factors is important to the distribution and establishment of halophytes (Ungar, 1998). In natural forest ecosystems, soils rarely contain an excess of salt because of natural drainage and flushing by precipitation. As a result, salt tolerance has not been extensively studied in woody plant species compared to herbaceous species (Renault et al., 1998).

Anthropogenically created conditions, such as the bitumen extraction methods (hot water digestion and flotation) currently in use in the Athabasca oil sands deposit in northeastern Alberta (Canada), by two operating oil sands plants (Syncrude Canada Ltd. and Suncor Energy, 1998), alone are producing large volumes of fluid tailings containing elevated concentrations of sodium, sulfate, bicarbonate and chloride ions. Syncrude Canada Ltd. (1998) alone produced about 75 million $\mathrm{m}^{3}$ of tailings in 1998 and the total disturbed areas requiring reclamation at closure is estimated at 22,000 ha of which tailings surface areas for dryland reclamation are $7500 \mathrm{ha}(\mathrm{Li}$ and Fung, 1998). Natural consolidation of the fluid tailings would require hundreds of years and are inappropriate for terrestrial reclamation. Therefore, emphasis is currently on composite tailings (CTs) reclamation in the oil sands industry in Alberta (Mikula et al., 1996a,b; TERRE, 1998). The composite tailings process consists of adding gypsum to fine tailings to produce nonsegregating deposit (CT) and release water (CT water). These CT materials are characterized by high levels of salt concentrations (excess sodium sulfate, chloride, $\mathrm{Ca}, \mathrm{Mg}$ ) and high alkalinity, which are major causes of plant toxicity. Demands of today's society, as expressed in recent reclamation laws of many provinces in Canada, are not just to stabilize soil and vegetation on disturbed areas but to reconvert them into productive agricultural and forested lands comparable to pre-disturbed terrain providing an integrated range of end uses and values associated with forests.
Previous studies have examined the tolerance of selected woody and herbaceous boreal plants to salts associated with these composite tailings, fine tailings and the waters they contain (Renault et al., 1998, 1999, 2000). Knowing the salt tolerance levels of various potential reclamation plant species is an important factor to ensure the survival and growth of plants onto saline habitats. In these studies, however, little attention was given to the intra-specific variability of the plants tested. The purpose of our study was to examine the inter- and intra-specific variability of selected boreal woody species to various salt concentrations using a semi-hydroponic system (Hambling et al., 2001) and to determine their potential suitability for reclamation of saline habitats.

\section{Materials and methods}

\subsection{Plant material}

Seeds of lodgepole pine (Pinus contorta Dougl. ex Loud. Var. latifolia Engelm.), jack pine (Pinus banksiana Lamb.), white spruce [Picea glauca (Moench) Voss], trembling aspen (Populus tremuloides Michx.), and red alder (Alnus rubra Bong.), were obtained from various sources (Table 1). The seeds were surface sterilized in $2 \%(\mathrm{v} / \mathrm{v})$ sodium hypochloride and rinsed six times with autoclaved water. They were then germinated in Metromix ${ }^{\circledR}$ (Grace Horticultural Products, W.R. Grace of Canada, Ajax, Ont.). When seedlings were $4-6 \mathrm{~cm}$ in height (about 2 weeks), they were transplanted into sand filled germination trays, in which each cell contained $50 \mathrm{~cm}^{3}$ of sand autoclaved twice for $45 \mathrm{~min}$ each time and completely saturated with water. The seedlings were left for 5 days without irrigation of treatment solutions to minimize transplantation shock.

\subsection{Experiment set-up in greenhouse}

A semi-hydroponic system (Hambling et al., 2001) was used. The sub-irrigation system is activated by a timer set to supply power to water pumps. When activated, the pumps flood large holding trays with treatment solution to approximately half the height of the germination trays three times a week for $15 \mathrm{~min}$ at a time. The solution is re-circulated allowing for 
Table 1

Description of seed sources (origin, seed lot number or name, supplier and geographic locations)

\begin{tabular}{|c|c|c|c|c|c|c|}
\hline Species & Origin & Seed lot & Supplier $^{\mathrm{a}}$ & Latitude $\left({ }^{\circ} \mathrm{N}\right)$ & Longitude $\left({ }^{\circ} \mathrm{W}\right)$ & Elevation (m) \\
\hline \multirow[t]{14}{*}{ A. rubra } & Englishman River, BC & 45958 & TSC & $49^{\circ} 13^{\prime}$ & $124^{\circ} 26^{\prime}$ & 400 \\
\hline & Mount Prevost, BC & 40473 & id. & $48^{\circ} 50^{\prime}$ & $123^{\circ} 47^{\prime}$ & 530 \\
\hline & Jordan River, BC & 40457 & id. & $48^{\circ} 41^{\prime}$ & $124^{\circ} 02^{\prime}$ & 5 \\
\hline & Tasu Inlet, BC & 33252 & id. & $53^{\circ} 40^{\prime}$ & $132^{\circ} 15^{\prime}$ & 37 \\
\hline & Skidgate, BC & 30017 & id. & $53^{\circ} 21^{\prime}$ & $131^{\circ} 57^{\prime}$ & 50 \\
\hline & Hanna Valley, BC & 39844 & id. & $53^{\circ} 15^{\prime}$ & $132^{\circ} 15^{\prime}$ & 100 \\
\hline & Exstew River, BC & 43086 & id. & $54^{\circ} 25^{\prime}$ & $129^{\circ} 09^{\prime}$ & 80 \\
\hline & Buckley Bay, BC & 46208 & id. & $49^{\circ} 33^{\prime}$ & $124^{\circ} 54^{\prime}$ & 100 \\
\hline & Kleindale, BC & 46242 & id. & $49^{\circ} 27^{\prime}$ & $123^{\circ} 57^{\prime}$ & 50 \\
\hline & Bachelor Bay, BC & Bachelor Bay & id. & $55^{\circ} 22^{\prime}$ & $126^{\circ} 55^{\prime}$ & 30 \\
\hline & Channel, BC & Channel & id. & $53^{\circ} 08^{\prime}$ & $132^{\circ} 15^{\prime}$ & 20 \\
\hline & Galiano Is., BC & Galiano Is. & id. & $48^{\circ} 57^{\prime}$ & $123^{\circ} 28^{\prime}$ & 50 \\
\hline & Kingcome Inlet, BC & Kingcome Inlet & id. & $51^{\circ} 30^{\prime}$ & $126^{\circ} 08^{\prime}$ & 30 \\
\hline & Port Renfrew, BC & Port Renfrew & id. & $48^{\circ} 36^{\prime}$ & $124^{\circ} 14^{\prime}$ & 20 \\
\hline \multirow[t]{5}{*}{ P. banksiana } & Nampa, AB & 8060006 & NTSC & $56^{\circ} 07^{\prime}$ & $116^{\circ} 55^{\prime}$ & 610 \\
\hline & Calling Lake, AB & 8960049 & id. & $55^{\circ} 46^{\prime}$ & $113^{\circ} 22^{\prime}$ & 600 \\
\hline & Fort Kent, AB & 9060060 & id. & $54^{\circ} 38^{\prime}$ & $110^{\circ} 51^{\prime}$ & 640 \\
\hline & Fort MacKay, AB & 9360060 & id. & $57^{\circ} 20^{\prime}$ & $111^{\circ} 23^{\prime}$ & 325 \\
\hline & Fort McMurray, AB & Syncrude & EAS & $57^{\circ} 02^{\prime}$ & $111^{\circ} 35^{\prime}$ & 315 \\
\hline \multirow[t]{3}{*}{ P. contorta } & Grande Prairie Forest, AB & 7665180 & NTSC & $55^{\circ} 10^{\prime}$ & $118^{\circ} 48^{\prime}$ & 650 \\
\hline & Woking, $\mathrm{AB}$ & 7960007 & id. & $55^{\circ} 40^{\prime}$ & $119^{\circ} 28^{\prime}$ & 800 \\
\hline & DS $66-10-5-84, \mathrm{AB}$ & 8461731 & id. & $54^{\circ} 38^{\prime}$ & $115^{\circ} 22^{\prime}$ & 930 \\
\hline P. glauca & Fort McMurray, AB & Syncrude & EAS & $57^{\circ} 02^{\prime}$ & $111^{\circ} 35^{\prime}$ & 315 \\
\hline \multirow[t]{4}{*}{ P. tremuloides } & Fort Nelson, BC & 40960 & TSC & $58^{\circ} 36^{\prime}$ & $122^{\circ} 20^{\prime}$ & 480 \\
\hline & Fort Nelson North, BC & 42307 & id. & $59^{\circ} 00^{\prime}$ & $123^{\circ} 12^{\prime}$ & 520 \\
\hline & Fort Nelson South, BC & 42308 & id. & $58^{\circ} 48^{\prime}$ & $122^{\circ} 12^{\prime}$ & 480 \\
\hline & Fort McMurray, AB & Syncrude & EAS & $57^{\circ} 02^{\prime}$ & $111^{\circ} 35^{\prime}$ & 315 \\
\hline
\end{tabular}

${ }^{a}$ TSC: Tree Seed Centre, Surrey, BC Ministry of Forests; NTSC: National Tree Seed Centre, Canadian Forest Service, Fredrickton, NB; EAS: Environmental Affairs Department, Syncrude Canada Ltd., Ft. McMurray, Alta.

mixing of the treatment solution and adequate aeration. We applied 121 of five different treatment solutions including a control of half strength Hoagland's solution (Hoagland and Arnon, 1938 in Hewitt, 1966), half strength Hoagland's solution prepared with CT release water, and three salinity treatments consisting of 25,50 and $75 \mathrm{mM}$ sodium chloride in half strength Hoagland's solution to five boreal woody species in a nested and two-factor factorial design (Montgomery, 1991). Seed lots are nested within species (Table 1). The CT release water was obtained from the small-scale (u-shaped cell) composite tailings trial at the Syncrude Canada Ltd. site near Ft. McMurray, Alta. The CT water chemistry consists of: $\mathrm{pH}, 8.26$; electrical conductivity, $6170 \mu \mathrm{S} / \mathrm{cm}$; $\mathrm{Ca}$, $55.2 \mathrm{mg} / \mathrm{l} ; \mathrm{Mg}, 33.2 \mathrm{mg} / \mathrm{l} ; \mathrm{Na}, 1580 \mathrm{mg} / \mathrm{l} ; \mathrm{K}, 34.1 \mathrm{mg} /$
1; $\mathrm{Fe}<0.04 \mathrm{mg} / \mathrm{l} ; \mathrm{Mn}<0.003 \mathrm{mg} / 1 ; \mathrm{SO}_{4}, 2020 \mathrm{mg} /$ 1; Cl, $691 \mathrm{mg} / \mathrm{l}$; hardness, $275 \mathrm{mg} / \mathrm{l}$; T Dis. Solids, $3950 \mathrm{mg} / 1 ; \mathrm{NO}_{2}$ and $\mathrm{NO}_{3}-\mathrm{N}<0.05 \mathrm{mg} / \mathrm{l}$. The experiment was set-up in a greenhouse with a daytime temperature of $21{ }^{\circ} \mathrm{C}$ and an $18{ }^{\circ} \mathrm{C}$ nighttime, natural light was supplemented with sodium halide lights with intensity of $450 \mu \mathrm{mol} \mathrm{m}^{-2} \mathrm{~s}^{-1}$ and a $15 \mathrm{~h}$ photoperiod. The relative humidity was approximately $35 \%$. The position of each treatment set-up was changed once a week to allow all units to be exposed to homogenous environmental conditions.

\subsection{Measurements and data analysis}

The experimental design was a nested design with crossed factors according the following mathematical 
model $Y_{i j k l}=\mu+\mathrm{Sp}_{i}+\operatorname{Tr}_{j}+\operatorname{Pr}(\mathrm{Sp})_{k(i)}+(\mathrm{Sp} \operatorname{Tr})_{i j}+$ $\operatorname{Tr} \operatorname{Pr}(\mathrm{Sp})_{j k(i)}+\varepsilon_{(i j k) l}$, where $Y_{i j k l}$ is a score for the given experimental unit in treatment combination $\operatorname{Tr} \operatorname{Pr}(\mathrm{Sp})_{j k(i)}, \mu$ the overall population mean, $\mathrm{Sp}_{j}$ the effect of the $i$ th species, $\operatorname{Tr}_{j}$ the effect of the $j$ th solution, $\operatorname{Pr}(\mathrm{Sp})_{k(i)}$ the effect of the $k$ th seed lot within the $j$ th species, $(\mathrm{Sp} \mathrm{Tr})_{i j}$ the joint effect of species and solution treatment, $\operatorname{Tr} \operatorname{Pr}(\mathrm{Sp})_{j k(i)}$ the interaction between treatment and seed lots within species, and $\varepsilon_{(i j k) l}$ the experimental error. Species and treatments were fixed factors, and seed lots were random factors. After 1 month of growth, survival, dry matter (biomass), and necrosis symptoms were recorded. The following scale was used for necrosis symptoms $\quad(0=$ none, $1=$ light, $2=$ moderate, $3=$ severe, $4=$ dead). Normality and homoscedasticity of data were tested using the SAS Univariate procedure, and the Brown-Forsythe test by SAS for Windows (SAS release 8.0, SAS, 1999). Normality and homoscedasticity were not achieved even after transformations. Therefore, the analysis of variance was conducted using both the RANK and GLM procedures and variance components were calculated with the VARCOMP procedure model = type 1 (SAS, 1999). Spearman correlations among growth traits and percent survival were computed from seed lot means over all solution treatments using the SAS CORR procedure. Proportionately ranked means for dry biomass production were obtained using the Bonferroni's correction for multiple pairwise comparisons with a maximum experimentwise error rate of 5\%. Stepwise multiple regression analysis was used to relate biomass production of seed lots with their geographic origins (latitude, longitude, and elevation). Latitude, longitude, and elevation of seed lot origin, and their squares and cross products, were used as independent variables. The probability used for a variable to enter the equation was 0.10 .

For practical ranking of seed lots for each species according to both their survival rate and dry biomass, we constructed a convex aggregation index (Khasa et al., 1995a). The formula constructed for this aggregation index was as follows:

$$
\begin{aligned}
\mathrm{AI} & =\delta \frac{v_{\mathrm{c} 1}-\left(v_{\mathrm{c} 1 \max }+v_{\mathrm{c} 1 \min }\right) / 2}{\left(v_{\mathrm{c} 1 \max }-v_{\mathrm{c} 1 \min }\right) / 2} \\
& +(1-\delta) \frac{v_{\mathrm{c} 2}-\left(v_{\mathrm{c} 2 \max }+v_{\mathrm{c} 2 \min }\right) / 2}{\left(v_{\mathrm{c} 2 \max }-v_{\mathrm{c} 2 \min }\right) / 2}
\end{aligned}
$$

where the $v_{\mathrm{c} 1}$ criterion represents the average value of survival rate and the $v_{\mathrm{c} 2}$ criterion represents the average dry biomass, and $\delta$ the weighting coefficient.

\section{Results}

The rank analysis of variance showed a significant interaction between salt treatments and seed lots within species as well as between salt treatments and species for the two measured traits (weight and necrosis, Table 2). The plant species, seed lots within species and salt treatments main effects were also significant (Table 2). The significant interaction plant genotype $\times$ salt treatment indicates a change in relative performance rank among genotypes from one salt treatment to the other. Based on variance components, the treatment and seed lot effects

Table 2

\begin{tabular}{|c|c|c|c|c|c|}
\hline \multirow[t]{2}{*}{ Source of variation } & \multirow[t]{2}{*}{ d.f. } & \multicolumn{2}{|l|}{ Necrosis } & \multicolumn{2}{|l|}{ Weight } \\
\hline & & $F$-value $(\operatorname{Pr}>F)$ & $\begin{array}{l}\text { Variance } \\
\text { component }(\%)\end{array}$ & $F$-value $(\operatorname{Pr}>F)$ & $\begin{array}{l}\text { Variance } \\
\text { component }(\%)\end{array}$ \\
\hline Treatment & 4 & $1135.78(<0.0001)$ & 57 & $157.54(<0.0001)$ & 18 \\
\hline Species & 4 & $191.54(<0.0001)$ & 8 & $157.21(<0.0001)$ & 15 \\
\hline Treatment $\times$ species & 16 & $15.89(<0.0001)$ & 3 & $5.00(<0.0001)$ & 1 \\
\hline Seed lot (species) & 23 & $38.30(<0.0001)$ & 10 & $39.69(<0.0001)$ & 25 \\
\hline Treatment $\times$ seed lot (species) & 88 & $5.42(<0.0001)$ & 6 & $3.11(<0.0001)$ & 7 \\
\hline Error & 1331 & & 15 & & 34 \\
\hline Total & 1466 & & 100 & & 100 \\
\hline
\end{tabular}

Anova on ranks and variance component for dependent variables weight and necrosis ${ }^{\mathrm{a}}$

\footnotetext{
"For "variance component" we used the Type 1 estimates method.
} 


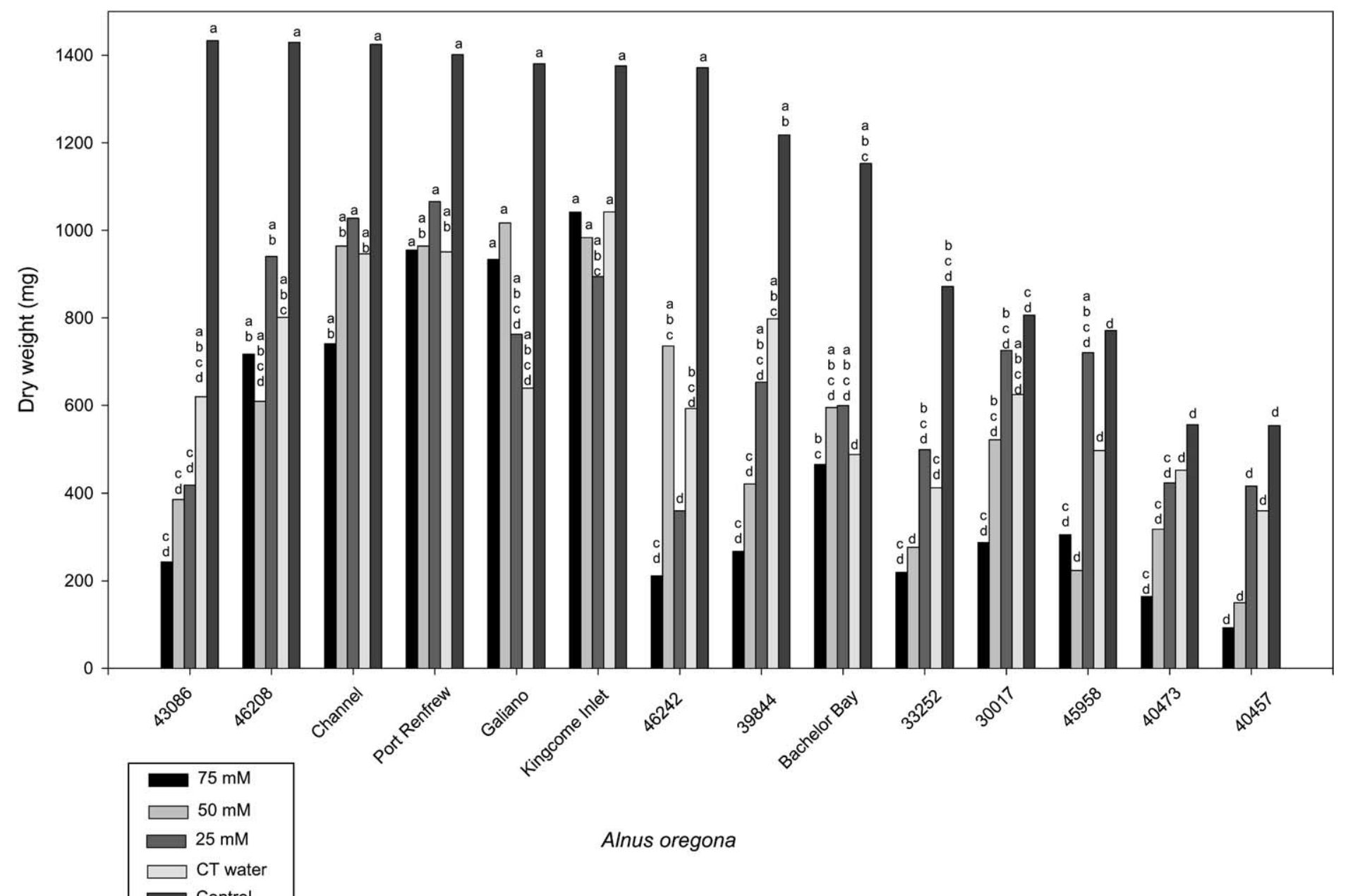

Fig. 1. Proportionally ranked means for dry matter (g) of different seed lots of A. rubra syn. A. oregona (a), P. tremuloides (b), P. banksiana (c), and P. contorta (d) at five salt treatments. Means followed by the same letter within each treatment are not significantly different at $5 \%$ significance level, using Bonferroni (Dunn) $t$-tests. 

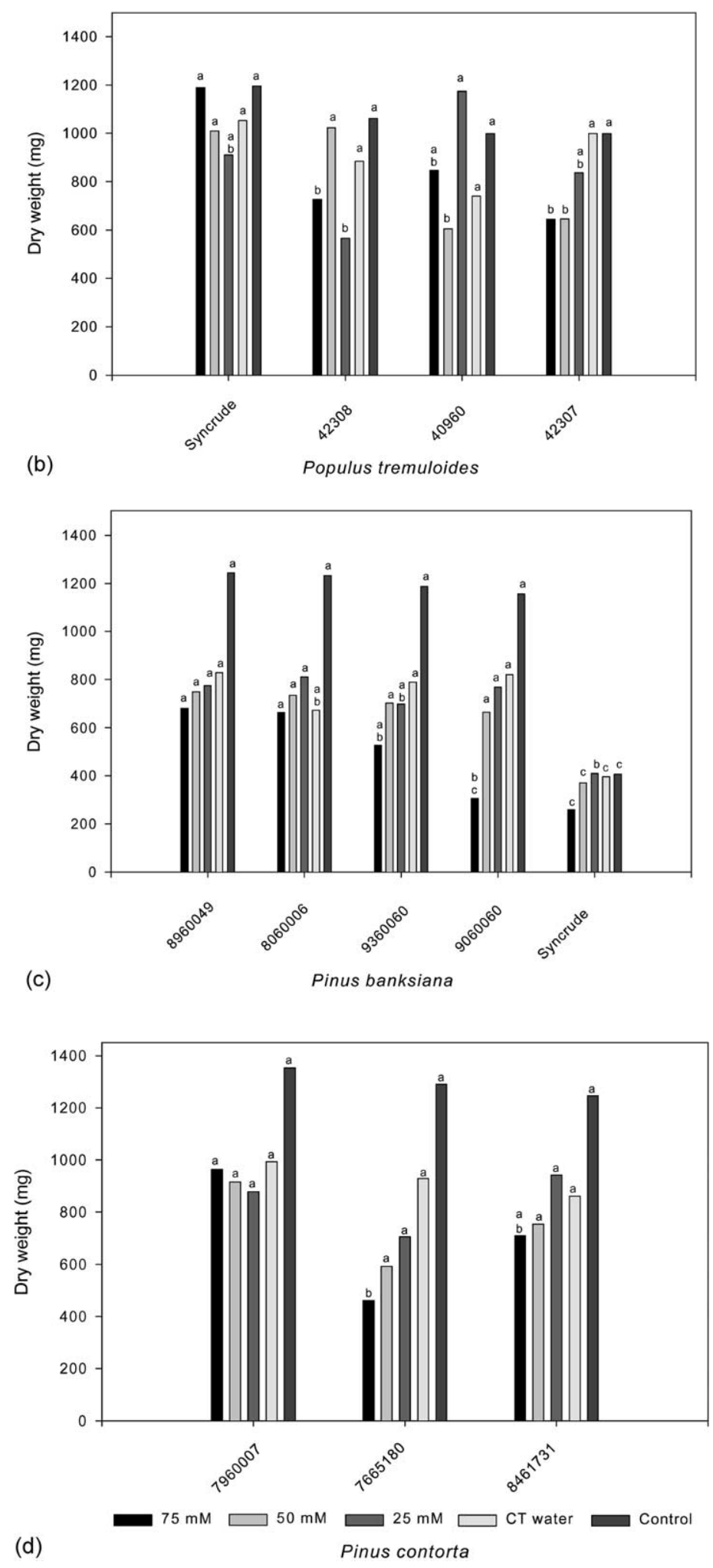

Fig. 1. (Continued). 
Table 3

Percent survival of the different seed lots and species under different salt treatments

\begin{tabular}{|c|c|c|c|c|c|c|c|}
\hline \multirow[t]{2}{*}{ Species } & \multirow[t]{2}{*}{ Seed lot } & \multicolumn{5}{|c|}{ Treatment $^{\mathrm{a}}$} & \multirow{2}{*}{$\begin{array}{l}\text { Average survival rate } \\
\text { over each seed lot }\end{array}$} \\
\hline & & 0 & 25 & 50 & 75 & $\mathrm{CT}$ & \\
\hline \multirow[t]{14}{*}{ A. rubra } & Bachelor & 83 & 0 & 0 & 0 & 0 & 17 \\
\hline & 46242 & 75 & 0 & 0 & 0 & 0 & 15 \\
\hline & Kingcome & 100 & 0 & 0 & 0 & 0 & 20 \\
\hline & Galiano & 100 & 0 & 0 & 0 & 0 & 20 \\
\hline & 39844 & 92 & 8 & 0 & 0 & 0 & 20 \\
\hline & 43086 & 100 & 0 & 0 & 0 & 0 & 20 \\
\hline & 46208 & 100 & 0 & 0 & 0 & 0 & 20 \\
\hline & Channel & 100 & 0 & 0 & 0 & 0 & 20 \\
\hline & Port Renfrew & 100 & 0 & 0 & 0 & 0 & 20 \\
\hline & 30017 & 100 & 42 & 0 & 0 & 17 & 32 \\
\hline & 45958 & 100 & 58 & 0 & 0 & 58 & 43 \\
\hline & 40473 & 100 & 33 & 0 & 0 & 83 & 43 \\
\hline & 40457 & 100 & 58 & 0 & 0 & 75 & 47 \\
\hline & 33252 & 100 & 50 & 0 & 0 & 50 & 40 \\
\hline Average & & 96.4 & 17.8 & 0 & 0 & 20.2 & 26.9 \\
\hline S.E. & & 2.1 & 6.5 & 0 & 0 & 8.4 & 2.9 \\
\hline \multirow[t]{4}{*}{ P. tremuloides } & 40960 & 83 & 0 & 0 & 0 & 0 & 17 \\
\hline & 42307 & 83 & 0 & 0 & 0 & 0 & 17 \\
\hline & 42308 & 100 & 0 & 0 & 0 & 0 & 20 \\
\hline & Syncrude & 100 & 0 & 0 & 0 & 0 & 20 \\
\hline Average & & 91.5 & 0 & 0 & 0 & 0 & 18.5 \\
\hline S.E. & & 4.9 & 0 & 0 & 0 & 0 & 0.9 \\
\hline \multirow[t]{5}{*}{ P. banksiana } & 9360060 & 100 & 8 & 0 & 0 & 0 & 20 \\
\hline & 8060006 & 100 & 0 & 0 & 0 & 33 & 27 \\
\hline & Syncrude & 100 & 92 & 100 & 67 & 100 & 92 \\
\hline & 8960049 & 100 & 17 & 0 & 0 & 50 & 33 \\
\hline & 9060060 & 100 & 0 & 0 & 0 & 27 & 25 \\
\hline Average & & 100 & 23.4 & 20 & 13.4 & 42 & 39.4 \\
\hline S.E. & & 0 & 17.4 & 20 & 13.4 & 16.6 & 13.3 \\
\hline \multirow[t]{3}{*}{ P. contorta } & 7665180 & 100 & 14 & 0 & 0 & 73 & 37 \\
\hline & 7960007 & 100 & 67 & 0 & 0 & 75 & 48 \\
\hline & 8461731 & 100 & 50 & 0 & 0 & 42 & 38 \\
\hline Average & & 100 & 43.7 & 0 & 0 & 63.3 & 41.0 \\
\hline S.E. & & 0 & 15.6 & 0 & 0 & 10.7 & 3.5 \\
\hline P. glauca & Syncrude & 100 & 92 & 92 & 50 & 17 & 70 \\
\hline
\end{tabular}

${ }^{a}$ See Section 2 for definition of treatments.

accounted for a substantial amount of the variation for the two measured traits. Spearman rank correlations were significant among necrosis, weight and percent survival for red alder; between necrosis and weight for aspen and white spruce; between necrosis and weight, and survival and weight for lodgepole pine (results not shown). Our results and discussion will focus more on weight and survival traits.

For red alder, the seed lots Kingcome Inlet, Galiano, Port Renfrew, Channel and 46208 produced the greatest amount of dry weight even at the highest salt concentration $(75 \mathrm{mM} \mathrm{NaCl})$ but were all dead at 
Table 4

Multiple regression of dry weight with geographic variables of seed lot origins (summary of stepwise selection by species ${ }^{\mathrm{a}}$ )

\begin{tabular}{|c|c|c|c|c|c|}
\hline Species & Variables in model & Model $R$-square & $F$-value $(\operatorname{Pr}>F)$ & Parameter estimate & Type 11 SS \\
\hline \multirow[t]{3}{*}{ A. rubra } & Intercept & & & 1548.73516 & 6651335 \\
\hline & Elevation $\times$ elevation & 0.7350 & $57.28(<0.0001)$ & -0.00164 & 11462585 \\
\hline & Latitude $\times$ longitude & 0.8700 & $10.63(0.0012)$ & -0.12081 & 1775989 \\
\hline \multirow[t]{2}{*}{ P. tremuloides } & Intercept & & & 8234.50870 & 2902044 \\
\hline & Latitude & 0.0660 & $16.82(<0.0001)$ & -125.59115 & 2299416 \\
\hline \multirow[t]{5}{*}{ P. banksiana } & Intercept & & & -41072.00000 & 1618413 \\
\hline & Latitude $\times$ elevation & 0.1283 & $41.01(<0.0001)$ & -1.82075 & 1140651 \\
\hline & Latitude $\times$ latitude & 0.1547 & $8.78(0.0033)$ & 15.31770 & 2802439 \\
\hline & Elevation & 0.2447 & $33.34(<0.0001)$ & 108.91621 & 1267921 \\
\hline & Longitude & 0.2809 & $14.06(<0.0001)$ & -89.43321 & 1230039 \\
\hline \multirow[t]{3}{*}{ P. contorta } & Intercept & & & -6476.5862 & 565866 \\
\hline & Latitude $\times$ latitude & 0.0215 & $3.44(0.0654)$ & 4.10406 & 592016 \\
\hline & Longitude $\times$ longitude & 0.0408 & $10.63(0.0784)$ & -0.36581 & 367579 \\
\hline
\end{tabular}

${ }^{\mathrm{a}}$ All variables left in models are significant at the $10 \%$ level using backward elimination procedure.

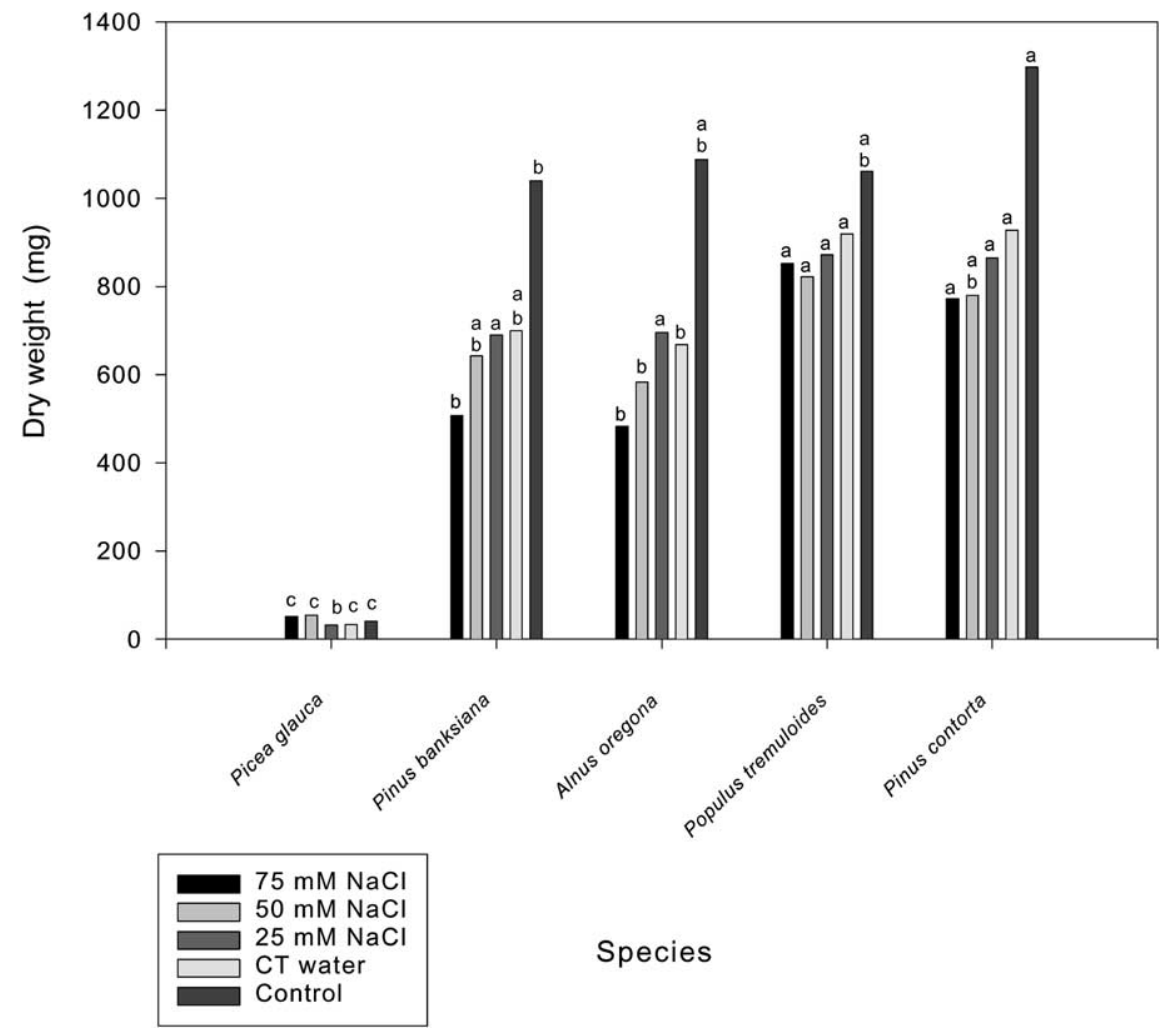

Fig. 2. Proportionally ranked means for dry matter (g) of different species used in this study. Means followed by the same letter within each treatment are not significantly different at $5 \%$ significance level, using Bonferroni (Dunn) $t$-tests. 
Table 5

Ranking of performance of species seed lots based on aggregation index $(\mathrm{AI})$

\begin{tabular}{|c|c|c|c|c|c|}
\hline \multirow[t]{2}{*}{$\begin{array}{l}\text { Species/seed } \\
\text { lot }\end{array}$} & \multicolumn{5}{|c|}{$\begin{array}{l}\text { Rankings based on AI weighting coefficients } \\
(0.1,0.2,0.3,0.4,0.5)\end{array}$} \\
\hline & $\delta=0.1$ & $\delta=0.2$ & $\delta=0.3$ & $\delta=0.4$ & $\delta=0.5$ \\
\hline \multicolumn{6}{|l|}{ A. rubra } \\
\hline Bachelor & 13 & 13 & 13 & 13 & 13 \\
\hline 46242 & 14 & 14 & 14 & 14 & 14 \\
\hline Kingcome & 6 & 6 & 6 & 5 & 1 \\
\hline Galiano & 9 & 9 & 9 & 9 & 6 \\
\hline 39844 & 11 & 11 & 11 & 11 & 11 \\
\hline 43086 & 12 & 12 & 12 & 12 & 12 \\
\hline 46208 & 10 & 10 & 10 & 10 & 9 \\
\hline Channel & 8 & 8 & 8 & 7 & 4 \\
\hline Port renfrew & 7 & 7 & 7 & 6 & 2 \\
\hline 30017 & 5 & 5 & 5 & 8 & 10 \\
\hline 45958 & 2 & 2 & 2 & 1 & 3 \\
\hline 40473 & 3 & 3 & 3 & 3 & 8 \\
\hline 40457 & 1 & 1 & 1 & 2 & 5 \\
\hline 33252 & 4 & 4 & 4 & 4 & 7 \\
\hline \multicolumn{6}{|l|}{ P. tremuloides } \\
\hline 40960 & 3 & 3 & 3 & 3 & 3 \\
\hline 42307 & 4 & 4 & 4 & 4 & 4 \\
\hline 42308 & 2 & 2 & 2 & 2 & 2 \\
\hline Syncrude & 1 & 1 & 1 & 1 & 1 \\
\hline \multicolumn{6}{|l|}{ P. banksiana } \\
\hline 9360060 & 5 & 5 & 5 & 5 & 4 \\
\hline 8060006 & 3 & 3 & 3 & 3 & 2 \\
\hline 8960049 & 2 & 2 & 2 & 2 & 1 \\
\hline 9060060 & 4 & 4 & 4 & 4 & 5 \\
\hline Syncrude & 1 & 1 & 1 & 1 & 3 \\
\hline \multicolumn{6}{|l|}{ P. contorta } \\
\hline 7665180 & 3 & 3 & 3 & 3 & 3 \\
\hline 7960007 & 1 & 1 & 1 & 1 & 1 \\
\hline 8461731 & 2 & 2 & 2 & 2 & 2 \\
\hline \multicolumn{6}{|l|}{ P. glauca } \\
\hline Syncrude & $\mathrm{ND}^{\mathrm{a}}$ & ND & ND & ND & ND \\
\hline
\end{tabular}

${ }^{\mathrm{a}}$ Not determined.

time of harvest (Fig. 1a, Table 3). These seed lots are "early fast-growing" and produced more dry biomass than any others before death. The seed lots 40457 , 40473, 45958 and 33252 had at least $40 \%$ average survival over all treatments (Table 3). For aspen, the Syncrude seed lot produced the greatest amount of dry weight at the highest salt concentration but all four seed lots were dead at the harvest time even at the lowest concentrations $(25 \mathrm{mM} \mathrm{NaCl})$ (Fig. 1b, Table 3). For jack pine, the seed lots 8960049, 8060006 and 9360060 produced the greatest amount of dry weight at all salt treatments and the Syncrude seed lot was the poorest (Fig. 1c). In contrast, the Syncrude seed lot had the greatest survival rate (92\%) over all treatments, followed by the seed lots 8960049 , 8060006, 9060060 and 9360060 (Table 3). For lodgepole pine, the seed lots 7960007 and 8461731 produced the greatest amount of dry weight at the highest salt treatment while the seed lots 7960007 and 7665180 had the highest percent survival (Fig. 1d, Table 3). The one white spruce seed lot from Syncrude tested in this study produced the least dry weight among the five tested species but was second best in survival after jack pine (Fig. 2, Table 3). Based on our study, lodgepole pine showed the greatest biomass followed by aspen, red alder, jack pine and white spruce (Fig. 2). Jack pine exhibited the highest percent survival followed by white spruce, red alder, and lodgepole pine (Table 3). Stepwise multiple regression analysis used to relate biomass production of seed lots with their geographic origins showed moderate amount of geographic variation with a coefficient of determination of 8.7, 6.6, 28.1 and $4 \%$ for red alder, aspen, jack pine, and lodgepole pine, respectively (Table 4).

By using the aggregation index (Khasa et al., 1995a), which takes into account two criteria (survival and dry weight), red alder (seed lot Nos. 40457 and 45958), aspen (Syncrude seed source), jack pine (Syncrude seed source), lodgepole pine (seed lot No. 7960007), seemed best amenable for revegetation of saline-alkaline sites such as the CT materials (see Table 5 for the following ranks). Varying relative weights given to the two criteria (Table 5) affected, the seed lot rankings little.

\section{Discussion}

Identifying suitable plant seed lots and families within-seed lots for CT reclamation is one of the important environmental issues being addressed by the oil sands industry in Alberta. Therefore, a rapid screening method is needed for assessing several plant species and genotypes for tolerance to toxic compounds such as those present in CT materials (Hambling et al., 2001). The CT materials are characterized by high levels of salt concentrations and alkalinity, and naphthenic acids, which are major causes of plant toxicity (Renault et al., 1999). This 
study has identified potential seed lots, which may be used for CT revegetation.

\subsection{Dry matter production and survival}

We have identified seed lots of woody plants that may produce more dry matter and have a good survival rate under saline conditions. Both of these measures of tolerance may be useful when selecting seed lots and families within-seed lots to grow at a given level of soil salinity. High salinity increased necrosis and decreased dry biomass of seedlings. These results are in agreement with other studies (Khan and Ungar, 1995; Renault et al., 1998, 2000; Rogers et al., 1996, 1997). Indeed, an excess of sodium salts in plant tissues can lead to enzyme inactivation, inhibition of nucleic acid and protein synthesis, membrane lesions that result in leakage of solutes from the cells and cause injury to tissues (Banuls et al., 1996; Renault et al., 1998, 2000). A study of different salts of $\mathrm{Na}^{+}$ and $\mathrm{K}^{+}$on the growth of Atriplex prostrata (Chenopodiaceae) showed that all plant growth parameters decreased with a lowering of the medium osmotic potential, and that $\mathrm{K}^{+}$salts were more inhibitory than $\mathrm{Na}^{+}$salts (Egan and Ungar, 1998). However, at low osmotic potential $(-1.5 \mathrm{MPa})$ the rate of germination was more inhibited by $\mathrm{Na}^{+}$salts than by $\mathrm{K}^{+}$salts (Egan et al., 1997). In some plants such as sorghum, an accumulation of $\mathrm{Na}^{+}$leads to a loss of potassium from leaves (Khan et al., 1995). Sodium toxicity impairs the germination and growth of plants and makes them more susceptible to pest and environmental stresses. Sodium also has an antagonsitic effect on $\mathrm{Ca}^{2+}$ and $\mathrm{Mg}^{2+}$ uptake. The decrease in $\mathrm{Mg}^{2+}$ could play a role in the observed leaf chlorosis, as $\mathrm{Mg}^{2+}$ is one of the key elements that compose the chlorophyll molecule essential for plant photosynthesis.

Salt tolerance in plants involves changes in morphology and in physiological processes (Greenway and Munns, 1980; Khan and Ungar, 1995). Several mechanisms have been proposed to explain salt resistance in woody plants including plant exclusion of $\mathrm{Na}^{+}$or $\mathrm{Cl}^{-}$(Allen et al., 1994) and ion compartmentalization in vacuoles to avoid toxic effects in the cytosol (Jacoby, 1994). Ungar (1991) divided halophyte plants into four groups based on their mechanism of ionic adjustment: (i) plants that restrict ion uptake, many of which belong to the
Poaceae, (ii) sodium and chloride accumulators, most of which are in the Chenopodiaceae, (iii) sulfate accumulators, represented by the Brassicaceae, and (iv) plants that accumulate a high concentration of inorganic ions, but are relatively low in organic substances (e.g., members of the Plantaginaceae).

It should be pointed out that stress resistance can vary among plant species and seed lots of plant species. For instance, in woody plants, oak has been reported to be more tolerant to salt stress than birch, Dutch elm and Norway spruce (Dragsted and Kubin, 1990). Salt tolerance in Eucalyptus camaldulensis Dehn (Karschon and Zohar, 1975) and Acer rubrum stress (Dochinser and Townsend, 1979) significantly differed depending on the seed source. Based on our study, lodgepole pine showed the greatest biomass, followed by aspen, red alder, jack pine and white spruce. Both lodgepole pine and jack pine exhibited a good survival rate at around $40 \%$ followed by red alder and aspen.

The CT water treatment with its phytotoxic compounds (Renault et al., 1998, 1999) is one of the best representations of the challenging problems facing the terrestrial reclamation in the oil sands industry. Based on the CT treatment, the following seed lots had at least $50 \%$ survival rate and may be used in the revegetation of CT: jack pine (seed lots Syncrude and 8960049), red alder (seed lot Nos. 40473, 40457, 45958, 33252), and lodgepole pine (seed lot Nos. 7960007 and 7665180). Overall treatments, the aggregation index indicated that red alder (seed lot Nos. 40457 and 45958), aspen (Syncrude seed source), jack pine (Syncrude seed source), lodgepole pine (seed lot No. 7960007) were the best performers. It is difficult to draw an informed decision on white spruce since we tested only one seed lot. The genetic variability of these species, suggests that emphasis be placed on intra-population sampling for both white spruce (King et al., 1984; Cheliak et al., 1985; Innes and Ringius, 1990) and aspen (Cheliak and Dancik, 1982; Hyun et al., 1987). Thus, it is worth testing more seed lots and families within-seed lots of these species to find the best suitable ones for CT revegetation. As well, it would have been better to test more seed lots in the previous studies involving several plant species native to the boreal forest (Renault et al., 1998, 1999), before making decisions on species performance to high salinity. Indeed, some species might be rejected outright because of 
susceptibility of one seed lot to high salinity. As an example, jack pine showed the lowest survival rate in the CT treatment (Renault et al., 1999). This is contrary to our findings where jack pine exhibited the highest percent survival because more seed lots were screened and some of them did exceptionally well in CT treatment (e.g., Syncrude seed lot, 100\% survival in CT treatment). Speckled alder [(Alnus incana ssp. Rugosa (Du Roi)], indigenous to Alberta, collected at the Syncrude site survived better to the salt treatments than the Pacific Northwest red alder but its germination rate was very low (data not shown). There is a need to understand the physiology and biochemistry of the speckled alder seeds in relation to germination. If the germination problems are overcome, seed lots/ families of this actinorhizal species could be inoculated with specific Frankia strains for CT revegetation.

The interaction genotype $\times$ environment (salt treatments in our case) was significant, meaning changes in relative performance rank among seedlings of species or seed lots within species from salt treatment to salt treatment. In other words, dry matter production of all species or seed lots within species did not decrease as salinity increased and there were significant differences in salt tolerance among seedlings of species or seed lots within species. Because genotype $x$ environment interactions exist, it is necessary to identify the sources of interactions before making decisions about species or seed lots within species selection and testing methods (Kremer, 1986; Khasa et al., 1995b,c). The variance components showed that most of the variation was explained by the treatment and seed lot effects. Renault et al. (1998) also observed a large individual variability in stress (CT water treatment) response of conifer seedlings for needle tip necrosis and water potentials. This suggests that there is a high degree of individual resistance within the species and that genetic differences should be considered in the selection of salt tolerant trees. Our results and others (Rogers et al., 1996, 1997) suggest that, in order to fully evaluate potential species for saline conditions, it may be worthwhile exploiting the intra-specific variation for dry matter production and survival that exists within species and selecting for increased productivity and survival. Therefore, the use of aggregation indices such as those presented in this study or more refined selection indices appears essential for the selection of seed lots and families, but also for clonal selection within-seed lots or families (Khasa et al., 1995a).

\subsection{Geographic patterns}

For red alder, differentiation among seed lots demonstrated geographic patterns with those from low elevations and south (early fast-growing seed lots) exhibiting the greatest amount of dry matter $\left(R^{2}=\right.$ $6.6 \%, p<0.0001$, see Tables 1 and 4 , Fig. 1). This negative elevational and latitudinal trends observed in the present study is in agreement with earlier studies by Xie et al. (1994) who found that seed lots from south, inland and low elevations tend to grow faster than those from north, coast and high elevations. Coastal seed lots may be more tolerant to salt because of sodium brought about by wet marine deposition (Khasa et al., 1995c). The study on genetic variability and performance of red alder in British Columbia showed that the genetic variability was substantial both among and within-seed lots for traits such as height, diameter, leaf abscission, and bud flushing (Xie et al., 1994). Dang et al. (1994) also found highly significant differences among seed lots in ecophysiological traits such as photosynthetic rate, mesophyll conductance, transpiration rate, stomatal conductance, stomatal sensitivity to water vapor pressure deficit, intercellular to ambient $\mathrm{CO}_{2}$ concentration ratio, and middy xylem water potential, but no significant between-seed lot differences in water use efficiency and no significant differences between families within-seed lot in any of the ecophysiological variables. For aspen, the latitude was important, with a negative trend $\left(R^{2}=6.6 \%, p<0.0001\right)$. In jack pine, the three geographic variables (longitude, latitude and elevation, $R^{2}=28.09 \%, p<0.0001$ ) were important. A study on height growth and survival of within- and between-seed lot crosses in jack pine has also shown these parameters were low at the most northern-most site as the latitude increased (Magnussen and Yeatman, 1988). In lodgepole pine, no significant trend was observed $\left(R^{2}=4.08 \%\right.$, $p=0.0389$ ). However, a rich structure of allozymic variation associated with geography was revealed; both latitude and longitude being important, with northern populations exhibiting a greater extent of genetic differentiation (Yeh et al., 1985). In white spruce, no trend could be derived since only one seed 
lot was used. However, Li et al. (1997) showed that patterns of white spruce seed lot variation followed mainly a south-north cline and to a lesser extent a west-east cline for height.

\section{Conclusion}

The considerable variability of long-lived woody species (Hamrick et al., 1992) suggests that attractive gains might be obtained through breeding programs aimed at developing salt tolerant tree genotypes. A tree improvement program could be time-consuming (Zobel and Talbert, 1991), but an early selection strategy with molecular markers, associated with tolerance to high levels of salts might be adopted to accelerate the rate of genetic improvement (Cheliak and Rogers, 1990; Tuskan, 1992; Monforte et al., 1996; Kubisiak et al., 2000) and the development of salt-tolerant lines.

Selection of the most promising ectomycorrhizal fungi for use in the saline-alkaline habitats has already been accomplished (Kernaghan et al., 2001). Therefore, the best seed lots selected in this study or families to be selected later can be inoculated with specific salttolerant ectomycorrhizal fungi. This work forms the basis for further studies to evaluate the inoculation biotechnology of tree seedlings or cuttings with these salt tolerant ectomycorrhizal fungi under field conditions over several seasons in order to fully assess the performance under saline soil conditions. A twostep procedure involving the selection of the plant genotypes and of their microsymbionts is likely to optimize the plant establishment and productivity on high salt-containing tailings generated from oil sands operations.

\section{Acknowledgements}

This research was supported by funding from ESTAC and Syncrude. We also thank Mr. Bruce Alexander (Greenhouse manager at the $\mathrm{U}$ of $\mathrm{A}$ ) and summer student Carrie Andrewes for the technical assistance. Special thanks are due to the Tree Seed Centre (Surrey, BC Ministry of Forests), the National Tree Seed Centre (Canadian Forest Service, Fredericton, NB) and the Environmental Affairs Department,
Syncrude Canada Ltd. (Ft. McMurray, AB) for providing us the seeds.

\section{References}

Allen, J.A., Chambers, J.L., Stine, M., 1994. Prospects for increasing the salt tolerance of forest trees: a review. Tree Physiol. 14, 843-853.

Banuls, J., Serna, M.D., Legaz, F., Talon, M.C., Primo-Millo, E., 1996. Growth and gas exchange parameters of citrus plants stressed with different salts. J. Plant Physiol. 150, 194-199.

Cheliak, W.M., Dancik, B.P., 1982. Genic diversity of natural populations of a clone-forming tree Populus tremuloides. Can. J. Genet. Cytol. 24, 611-616.

Cheliak, W.M., Rogers, D.L., 1990. Integrating biotechnology into tree improvement programs. Can. J. For. Res. 20, 452-463.

Cheliak, W.M., Pitel, J.A., Murray, G., 1985. Population structure and the mating system of white spruce. Can. J. For. Res. 15, 301-308.

Curtin, D., Steppuhn, H., Selles, F., 1993. Plant responses to sulfate and chloride salinity: growth and ionic relations. Soil Sci. Soc. Am. J. 47, 1304-1310.

Dang, Q.L., Xie, C.Y., Ying, C., Guy, R.D., 1994. Genetic variation of ecophysiological traits in red alder (Alnus rubra Bong.). Can. J. For. Res. 24, 2150-2156.

Dochinser, L.S., Townsend, A.M., 1979. Effects of roadside deicer salts and ozone on red maple progenies. Environ. Pollut. 19, 229-237.

Dragsted, J., Kubin, E., 1990. Some results from Danish investigations in salt stress on trees. In: Proceedings of the SNS Seminar on Stress in Nature, Oulanka, Finland, September 1989. Aquilo. Ser. Botanica 29 21-23.

Egan, T.P., Ungar, A., 1998. Effect of different salts of sodium and potassium on the growth of Atriplex prostrata (Chenopodiaceae). J. Plant Nutr. 21, 2193-2205.

Egan, T.P., Ungar, I.A., Meekins, J.F., 1997. The effect of different salts of sodium and potassium on the germination of Atriplex prostrata (Chenopodiaceae). J. Plant Nutr. 20, 1723-1730.

Greenway, H., Munns, R., 1980. Mechanisms of salt tolerance in nonhalophytes. Ann. Rev. Plant Physiol. 31, 149-190.

Hambling, B., Fung, M., Kernaghan, G., Khasa, P.D., 2001. Good nutrition: growers can rely on semi-hydroponics to monitor plants' nutrient needs and assess other factors such as optimal $\mathrm{pH}$ and salinity. Am. Nurseryman, 52-53.

Hamrick, J.L., Godt, M.J.W., Sherman-Broyles, S.L., 1992. Factors influencing levels of genetic diversity in woody plant species. New For. 6, 95-124.

Hewitt, E.J., 1966. Sand and Water Culture Methods Used in the Study of Plant Nutrition. Technical Communication No. 22 (Revised 2nd Edition). Commonwealth Agricultural Bureaux, Farnham, Bucks, England.

Hoagland, D.R., Arnon, D.I., 1938. The water-culture method for growing plants without soil. Circ. Calif. Agric. Exp. Stat., 347 and Rep. Smithsonian Inst. 1938. Miscellaneous Publication No. 3514, 1939, 461 pp. 
Hyun, J.O., Rajora, O.P., Zsuffa, L., 1987. Genetic variation in trembling aspen in Ontario based on isozyme studies. Can. J. For. Res. 17, 1134-1138.

Innes, D.J., Ringius, G.G., 1990. Mating system and genetic structure of two populations of white spruce (Picea glauca) in eastern Newfoundland. Can. J. Bot. 68, 1661-1666.

Jacoby, B., 1994. Mechanisms involved in salt tolerance by plants. In: Pessakakli, M. (Ed.), Handbook of Plant and Crop Stress. Marcel Dekker, New York, pp. 97-125.

Karschon, R., Zohar, Y., 1975. Effects of flooding and irrigation water salinity on Ecalyptus camaldulensis Dehn. from three seed sources (Leaflet No. 54). Division of Forestry, Agric. Res. Org. Israel.

Kernaghan, G., Hambling, B., Fung, M., Khasa, P.D., 2001. In vitro selection of ectomycorrhizal fungi for use in reclamation of saline-alkaline habitats. Restoration Ecol., in press.

Khan, A., Ungar, I.A. (Eds.), 1995. Biology of Salt Tolerant Plants. Department of Botany, University of Karachi, Karachi, Pakistan.

Khan, A., Ashraf, M.Y., Navqvi, S.S.M., Khanzada, B., Ali, M., 1995. Growth, ion and solute contents of sorghum grown under $\mathrm{NaCl}$ and $\mathrm{Na}_{2} \mathrm{SO}_{4}$ salinity stress. Acta Physiol. Plant. 17, 261268.

Khasa, P.D., Vallée, G., Bousquet, J., 1995a. Provenance variation in rooting ability of juvenile stem cuttings from Racosperma auriculiforme and $R$. mangium. For. Sci. 41, 305-320.

Khasa, P.D., Li, P., Vallée, G., Magnussen, S., Bousquet, J., 1995b. Early evaluation of Racosperma auriculiforme and R. mangium provenance trials on four sites in Zaire. For. Ecol. Manage. 78, 99-113.

Khasa, P.D., Vallée, G., Li, P., Magnussen, S., Camiré, C., Bousquet, J., 1995c. Performance of five tropical tree species on four sites in Zaire. Common. For. Rev. 74, 129-137.

King, J.N., Dancik, B.P., Dhir, N.K., 1984. Genetic structure and mating system of white spruce (Picea glauca) in a seed production area. Can. J. For. Res. 14, 639-643.

Kremer, A., 1986. Les variations d'expression du génotype (corrélation juvénile-adulte et interaction genotype $\times$ milieu): approche quantitative et explicative. Rev. For. Fr. 38, 4047.

Kubisiak, T.L., Nelson, C.D., Nowak, J., Friend, A.L., 2000. Genetic linkage mapping of genomic regions conferring tolerance to high aluminum in slash pine. In: Mitchell, A.K., Puttonen, P., Stoehr, M., Hawkins, B.J. (Eds.), Frontiers of Forest Biology. Proceedings of the 1998 Joint Meeting of the North American Forest Biology Workshop and the Western Forest Genetics Association. J. Sustainable For. 10 6978.

Li, P., Beaulieu, J., Bousquet, J., 1997. Genetic structure and patterns of genetic variation among populations in eastern white spruce (Picea glauca). Can. J. For. Res. 27, 189-198.

Li, X., Fung, M.Y.P., 1998. Creating soil-like materials for plant growth using tailings sand and fine tails. J. Can. Petroleum Tech. 37, 44-47.

Magnussen, S., Yeatman, C.W., 1988. Height growth and survival of within- and between-provenance crosses in jack pine. Can. J. For. Res. 18, 1145-1151.
Mikula, R.J., Kasperski, K.L., Burns, R.D., 1996a. Consolidated tailings release water chemistry. In: Balkema, A.A. (Ed.), Tailings and Mine Waste'96. Rotterdam, pp. 459-468.

Mikula, R.J., Kasperski, K.L., Burns, R.D., Mikula, R.J., Kasperski, K.L., Burns, R.D., MacKinnon, M.D., 1996b. Nature and fate of oil sands fine tailings. Adv. Chem. 251, 677-723.

Monforte, A.J., Asins, M.J., Carbonell, E.A., 1996. Salt tolerance in Lycopersicon species. IV. Efficiency of marker-assisted selection for salt tolerance improvement. Theoret. Appl. Genet. 93, 765-772.

Montgomery, D.C., 1991. Design and Analysis of Experiments, 3rd Edition. Wiley, New York.

Renault, S., Lait, C., Zwiazek, J.J., MacKinnon, M., 1998. Effect of high salinity tailings waters produced from gypsum treatment of oil sands tailings on plants of the boreal forest. Environ. Pollut. 102, 177-184.

Renault, S., Paton, E., Nilsson, G., Zwiazek, J.J., MacKinnon, M., 1999. Responses of boreal plants to high salinity oil sands tailings water. Environ. Pollut. 107, 357-365.

Renault, S., Zwiazek, J.J., Fung, M., Tuttle, S., 2000. Germination, growth and gas exchange of selected boreal forest seedlings in soil containing oil sands tailings. Environ. Pollut. 107, 357-365.

Rogers, M.E., Noble, C.L., Pederick, R.J., 1996. Identifying suitable grass species for saline areas. Aust. J. Exp. Agric. 36, 197-202.

Rogers, M.E., Noble, C.L., Pederick, R.J., 1997. Identifying suitable temperate forage legume species for saline areas. Aust. J. Exp. Agric. 37, 639-645.

SAS, 1999. SAS for Windows, Release 8.0. SAS Institute, Inc., Cary, NC.

Syncrude Canada Ltd., 1998. Leases 17 and 22 EPEA Approval Amendment Application. Fort McMurray, Alberta.

Szabolics, I., 1994. Soils and salinization. In: Pessarakli, M. (Ed.), Handbook of Plant and Crop Stress. Marcel Dekker, New York, pp. 3-11.

TERRE, 1998. Terrestrial reclamation of challenging materials in the oil sands industry. In: Proceedings of the TERRE Workshop, Edmonton, Alberta, January 29-30, 1998.

Tuskan, G.A., 1992. Marker-aided selection: a tool for the improvement of forest tree species. Can. J. For. Res. 22, 9991000.

Ungar, I.A., 1991. Ecophysiology of Vascular Halophytes. CRC Press, Boca Raton, FL.

Ungar, I.A., 1998. Are biotic factors significant in influencing the distribution of halophytes in saline habitats. Bot. Rev. 64, 176-199.

Xie, C.Y., Ying, C.C., Courtin, P., 1994. Genetic variability and performance of red alder (Alnus rubra) in British Columbia. In: Proceedings of the Ecology Management of B.C. Hardwoods, Delta Pacific Hotel and Conference Centre, Richmond, BC, December 1-2, 1993, pp. 147-156.

Yeh, F.C., Cheliak, W.M., Dancik, B.P., Illingworth, K., Trust, D.C., Pryhitka, B.A., 1985. Population differentiation in lodgepole pine, Pinus contorta spp. latifolia: a discriminant analysis of allozyme variation. Can. J. Genet. Cytol. 27, 210-218.

Zobel, B., Talbert, J., 1991. Applied Forest Tree Improvement. Waveland Press, Illinois. 